\title{
Impact of electromobility development on the electricity market
}

\author{
Mikołaj KOŁTONOWSKI, Remigiusz KOŁTONOWSKI, Stanisław PAŁUBICKI
}

DOI: 10.30464/jmee.2021.5.1.53

Cite this article as:

Kołtonowski M., Kołtonowski R., Pałubicki S. Impact of electromobility development on the electricity market. Journal of Mechanical and Energy Engineering, Vol. 5(45), No. 1, 2021, pp. 53-58.

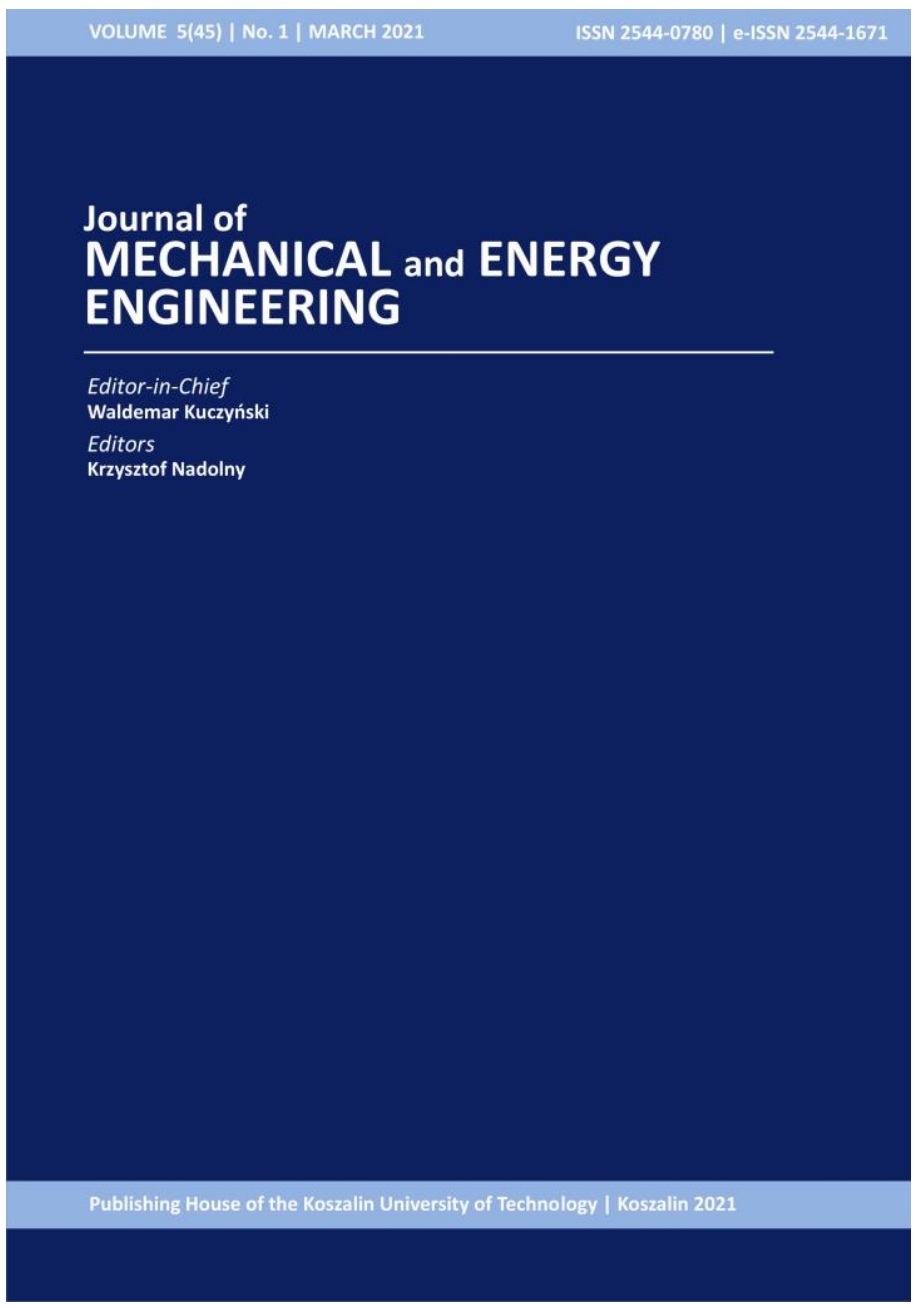

\section{Journal of Mechanical and Energy \\ Engineering}

Website: jmee.tu.koszalin.pl

ISSN (Print): 2544-0780

ISSN (Online): 2544-1671

Volume: 5(45)

Number: 1

Year: 2021

Pages: 53-58

Article Info:

Received 11 February 2021

Accepted 25 February 2021

\section{Open Access}

This article is distributed under the terms of the Creative Commons Attribution 4.0 (CC BY 4.0) International License (http://creativecommons.org/licenses/by/4.0/), which permits unrestricted use, distribution, and reproduction in any medium, provided you give appropriate credit to the original author(s) and the source, provide a link to the Creative Commons license, and indicate if changes were made. 


\title{
IMPACT OF ELECTROMOBILITY DEVELOPMENT ON THE ELECTRICITY MARKET
}

\author{
Mikołaj KOŁTONOWSKI ${ }^{1}$, Remigiusz KOŁTONOWSKI ${ }^{2}$, Stanisław PAŁUBICKI ${ }^{3 *}$ \\ ${ }^{1}$ Faculty of Mechanical Engineering, Department of Energetics, Koszalin University of Technology, \\ Raclawicka 15-17, 75-620 Koszalin, Poland, \\ ${ }^{2}$ Faculty of Mechanical Engineering, Department of Production Engineering, Koszalin University of \\ Technology, Raclawicka 15-17, 75-620 Koszalin, Poland, \\ $3^{3 *}$ Faculty of Mechanical Engineering, Department of Production Engineering, Koszalin University of \\ Technology, Raclawicka 15-17, 75-620 Koszalin, Poland, e-mail: stanislaw.palubicki@tu.koszalin.pl
}

(Received 11 February 2021, Accepted 25 February 2021)

\begin{abstract}
The article describes the forecasts and the current state of electromobility in Poland. Attention was drawn to the significant problems facing the electricity market as a result of adapting the infrastructure for electromobility and growing energy demand. Integrated systems connecting electric vehicles, transport infrastructure, energy networks, buildings and renewable energy sources supporting electromobility were presented. It also shows the activities undertaken by Energa Operator for the development of electromobility in the area of electricity distribution of the company.
\end{abstract}

Keywords: electromobility, smart grid, vehicle to grid, power engineering, Energa Operator.

\section{INTRODUCTION}

Electromobility is all the issues related to the use of electric vehicles which today constitute a serious alternative to vehicles with internal combustion engines. Electric vehicles are seen as a tool to combat smog and climate change [13]. This is a correct statement because emission of harmful gases by an electric car may be reduced to the emission of pollutants from the power plant stack if the charger is powered by a conventional source of electricity [14]. One of the causing factors the growing popularity of electric cars is also the increase in the total number of vehicles and hance the expansion of public roads [19]. In 2019, electric cars accounted for over $50 \%$ of all cars sold in Norway, what confirms the forecast that electric transport will dominate over several decades [18]. More electric vehicles means a greater demand for electricity and this forces many changes in the electricity sector.

\section{ELECTROMOBILITY IN POLAND}

According to data from the end of February 2020, there were 9803 electric cars on Polish roads, of which $58 \%$ were fully electric vehicles (BEV), the rest were plug-in hybrids (PHEV) - (Fig. 1).

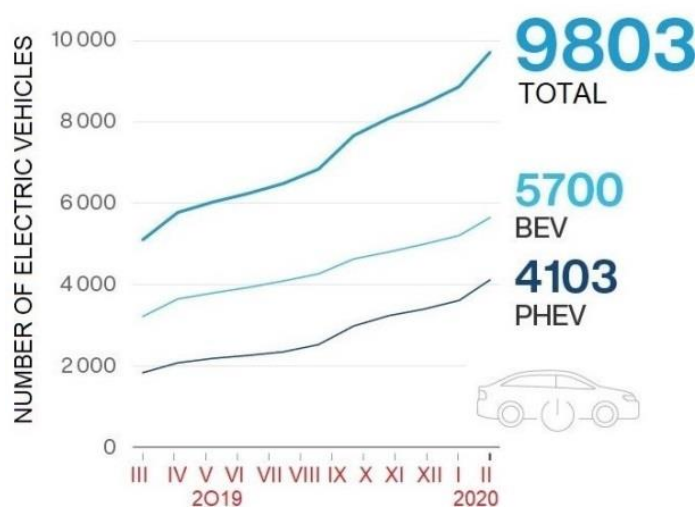

Fig. 1. Growth curve of the number of electric vehicles in Poland from March 2019 to February 2020 [21]

In February 2020, there was an over 50\% increase in the number of electric vehicles compared to the previous year [21]. At the time, there were 1093 electric vehicles charging station in Poland, including 2028 charging points. $30 \%$ of them were fast DC charging stations and $70 \%$ were slow AC chargers with a power less than or equal to $22 \mathrm{~kW}$ [21], of which the most chargers are located in Warsaw (Fig. 2). 


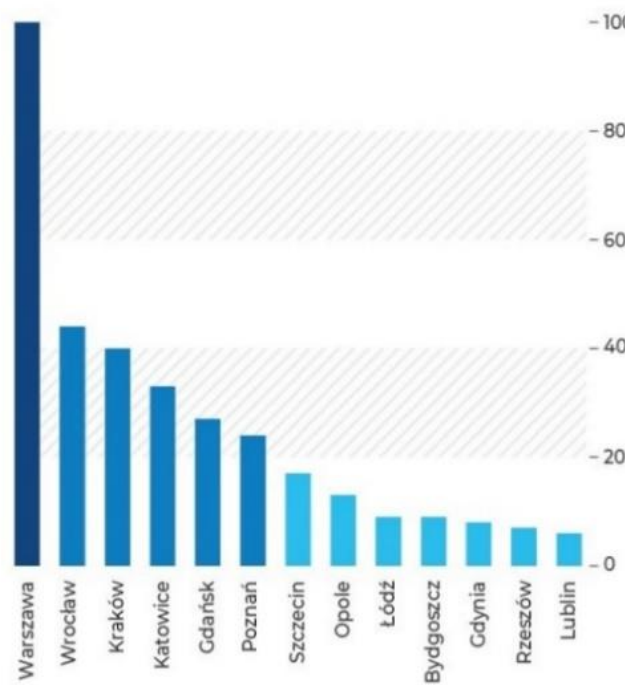

Fig. 2. Electric car charging stations in individual Polish cities [21]

\section{THE FORECASTS OF ELECTROMOBILITY}

The forecasts presented by the Ministry of Energy in the electromobility development plan (Fig. 3) assume the achievement of one million electric cars on Polish roads in 2025 . As can be seen in the diagram, by 2040 almost $100 \%$ share of electric vehicles in Poland is forecast $[17,22]$.

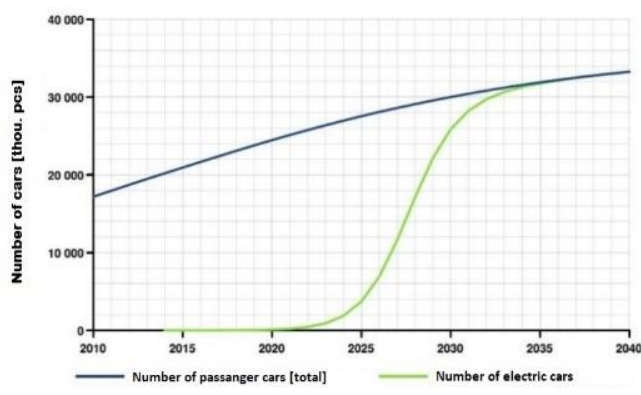

Fig. 3. Forecast of the number of cars in Poland over the years [22]

By the end of 2020, it is planned to build approx. 6000 points with normal charging power (up to 22 $\mathrm{kW}$ ) and 400 points with high charging power. Even the weakest chargers can have the power equal to the power of all other electrical appliances in the household (usually it is definitely less than $10 \mathrm{~kW}$ ), and the more powerful ones already constitute a serious burden on the local power grid. Nationwide, the power of the charger system is to reach $182 \mathrm{MW}$ [22].

\section{THE CHALLENGES FOR THE POWER INDUSTRY}

The electromobility development plan assumes that with the average ten-year life of a car, the revenues of energy companies from the sale of energy for this purpose may reach even 20 million PLN [17]. The total annual demand for electricity is about 170 $\mathrm{TWh}$, reaching the number of one million electric vehicles by 2025 is to generate an additional demand of about 2,3-4,3 TWh [20] which is undoubtedly a challenge for the national energy system and an opportunity for companies from industry that will have adapt the infrastructure to the existing needs $[17,3,15]$.

\subsection{Modernization of the power transmission and distribution grid}

Power grids were built mostly a quarter of a century ago and are not adapted to the loads that will arise when thousands of chargers are connected to them [1]. According to the data, the covers almost 300000 kilometers of medium voltage grid [11]. The dynamic development of electromobility is an opportunity to expand and modernize the existing electrical grid. Investments in the existing distribution and transmission grid are important, especially in the areas where the installation of new charging stations is planned, especially those equipped with energyconsuming high-power chargers [20]. In addition, technical requirements related to the possibility of installing chargers should be taken into account event where such stations are not installed at present. New building should be equipped with connections with sufficient power to install chargers - this applies especially to office buildings and buildings of public institutions where the installation of chargers seems to be a necessity due to the dynamic development of electromobility [17].

\subsection{Flattening of the Energy demand curve}

The average demand for electricity in Poland between 8:00 a.m. and 8 p.m. is approx.. 23-24 GW, but during the night hours (especially between midnight and 6:00 am) the demand drops even by a third, to approximately 15-16 GW [19]. A larger number of electric cars, if not properly managed may lead to an increase in differences in electricity demand during the day. The inclusion of electric vehicles in the balancing of the energy system may lead to the shift of the KSE in such a way to the power demand will decrease in the peak period and increase in offpeak periods [16]. This can be achieved for example, by introducing a dynamic tariff which will be relatively lower when the energy demand is lower. The purposed solution is also the continuation of the renewable energy sources sector, in particular with regard to prosumer installations (Fig. 4) [13]. 


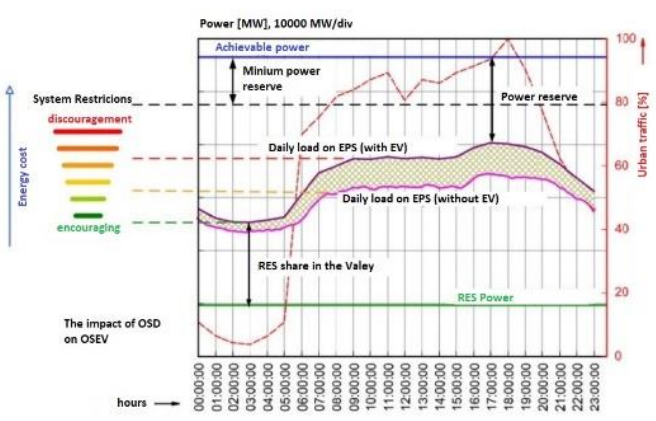

Fig. 4. Projected electricity consumption related to the increase in the number of electric cars [2]

\subsection{Smart Grid}

Smart grid can be defined as a "system of systems" - a platform that combines the functioning of various technologies and IT systems [4]. It is also an electricity system that integrates the activities of all participants of the energy market: generation, transmission, distribution, sale and users (Fig. 5).

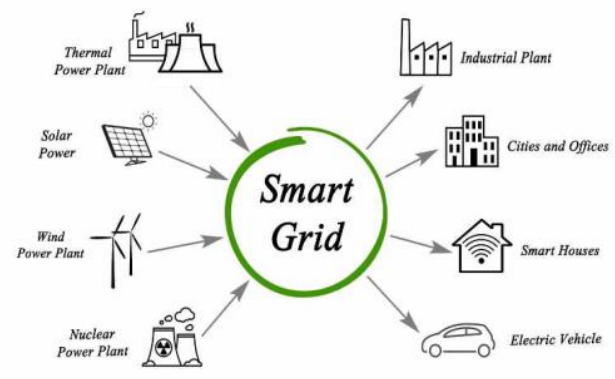

Fig. 5. Smart Grid operation diagram [10]

Smart Grid is an essential component in meeting the challenge of increasing energy consumption including through electromobility [4]. The use of this system allows for effective control of all including distributed elements of the power grid. It is also an extensive measurement system that provides information about the entire network in real time [12]. By using Smart Grid utility companies have the tools to forecast the maximum and minimum demand and to efficiently manage the farthest points of the power grid. This system allows for high energy savings, reducing its costs and increasing the reliability of supplies (Fig. 6) [23].

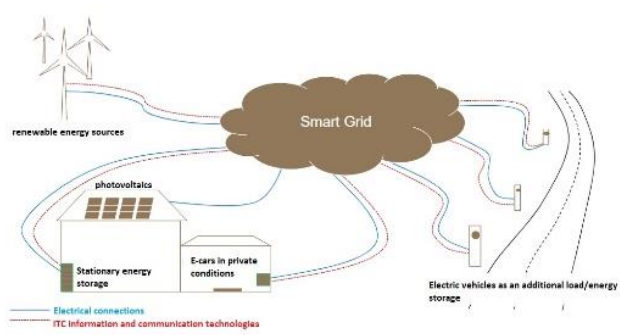

Fig. 6. Electric vehicles in the Smart Grid [5]

\subsection{Smart Charging}

Smart Charging is a system that allows to remotely control the power of a car charger in two directions. As a result the operator of distribution grid with the consent of electric vehicle user is able to plan an optimal technically and economically charging schedule. This tool can also be used to study the impact of modern car chargers on the operation of the power grid. Knowing the location of the connected vehicle in the grid, the power of charger and the range of active and reactive power controls, the operator can test the influence of systems, e.g. for local balancing of low voltage grid [12].

\subsection{Vehicle to Grid}

Vehicle to grid (Fig. 7) is a system that enables a two-way flow of energy between an electric vehicle and the power grid [19]. In practice, this means that if there are vehicles connected to the grid on a given area and there is a large of demand for electricity in this area then through the $\mathrm{V} 2 \mathrm{G}$ system it will be taken from the vehicle in certain amounts and returned to the grid instead of sending it to the gird from power station many kilometers away. Under certain conditions, such a solution may pay off, for example, because there is no need to increase the power of operating power plants. When the demand for electricity is small vehicles would be recharged [7].

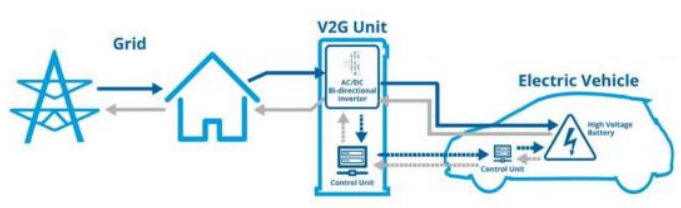

Fig. 7. Schematic diagram of the V2G [9]

Energy from vehicles can be used by the recipient or by the national power system to improve the quality of energy, increase the reliability of supplies or to reduce the costs of energy supplies. The implementation of such functionality for the power system will require an appropriate number of vehicles on the market [19]. The use of V2G would be the most effective during the maximum production from renewable energy sources, then the generated electricity could be stored in vehicle batteries and be used by the vehicle when it is needed or sent back to the grid [6].

\section{DEVELOPMENT OF \\ ELECTROMOBILITY IN THE AREA \\ OF OPERATION THE ENERGA OPERATOR GROUP}

Due to the provisions of the Act on electromobility and alternative fuels, energy distribution companies are obliged to build charging stations in their area and in large cities. Energa Trading is expanding publicly 
available charging stations for electric cars - currently it has launched 36 charging stations, about $1 / 3$ are fast DC stations with a power of $50 \mathrm{~kW}$, powered by green energy. In 2020, in Koszalin, a fast DC station was launched and 27 new charging stations are also planned in this city.

There are plans to build connections for commercially planned stations for all operators of generally accessible charging stations. The company Energa Lighting is also planning a pilot charging stations on lighting poles (Fig. 8) to supplement the Group's offer, among others for block residents.

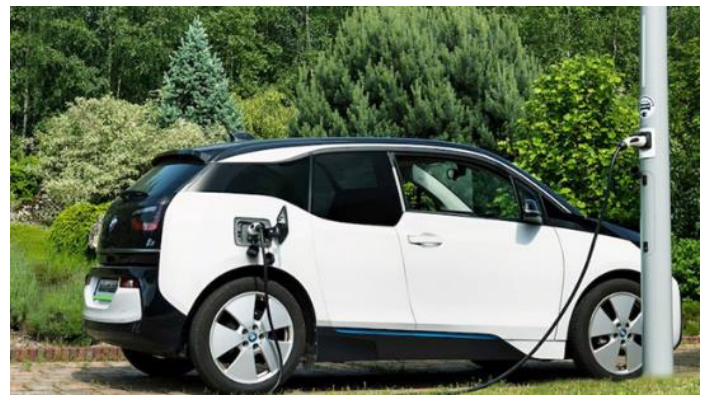

Fig. 8. Charger in the lighting pole [8]

Energa Group is also interested in using the V2G technology, which is at an early stage of development and has not been commercially implemented in Poland so far. Based on our own experience and the market environment, it is possible that this technology will be used within a few years.

Currently, connecting points for charging electric cars in most cases in the aera of operation of the Energa Group is not a problem for distribution grid. Connecting significant power at some point may require reconstruction of the network, e.g. due to insufficient connection capacity, this is achieved by modernizing the network, e.g. increasing the transformer power, increasing the cable cross-section. Along with the development of electromobility and the increasing number of electric vehicles, distribution system operator and energy consumers (housing communities, office owners, etc.) will be obliged to use modern IT systems to meet the expectations of customers related to bidirectional flow of electricity (V2G) or the implementation of intelligent charging Smart Charging, adjusting the maximum connection power to the number of vehicles charged at a specific time.

Electric car owners mostly charge their cars at home overnight. These customers can take advantage of the G12 tariff which allows the vehicle to be charged at night with cheaper electricity. Additional incentive for the Energa Group to purchase electric cars is still the free and generally available grid of charging stations which ensures that the electric car is charged only with green energy (Fig. 9). In the future, as the number of electric vehicles in-creases, the Energa Group will also expand its offer.
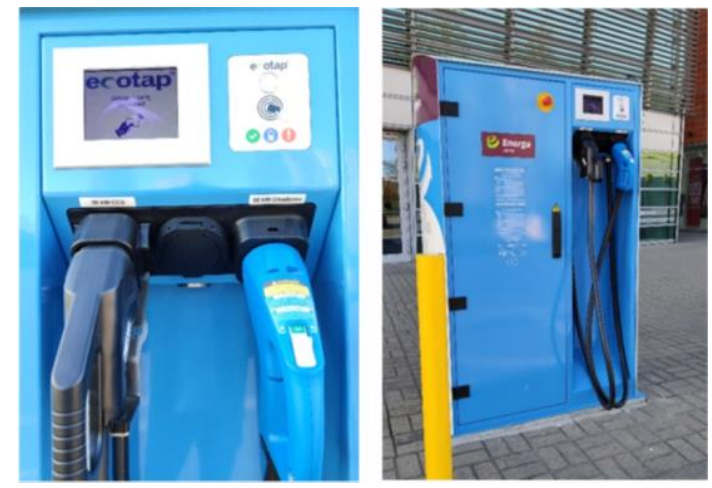

Fig. 9. $50 \mathrm{~kW}$ charger at the EMKA gallery in Koszalin

\section{SUMMARY}

The analysis of the state of knowledge and technology related to the topic of the article allowed for the formulation of the following conclusions.

1. The development of electromobility in Poland will undoubtedly have an impact on the electricity market. While in the initial stage of development of electromobility, the impact on the energy sector will be low, with one million electric cars it may be significant.

2. The development of electromobility may help the Polish energy sector. In the initial phase, the investment needs resulting from the introduction of electric cars to the market will allow for the strengthening and expansion of transmission and distribution grid.

3. Popularization of electric cars will create an opportunity to better balance the system, develop the night valley and integrate renewable energy sources.

4. In the long term, electromobility may cause popularization of revolutionary solutions, such as energy storage.

5. Replacing combustion engine vehicles with electric cars will have a positive impact on air quality due to the low emission of these vehicles.

6. Ambitious goals for the development of electromobility will also force investments in smart grids and metering. Without investment in smart metering and software, charging cars will be an additional burden on the grid and factor destabilizing its work. This is related to the behavior patterns of car owners who charge them at the same time. 


\section{References}

1. Atmoterm (2019): Raport końcowy, Analiza stanu rozwoju oraz aktualnych trendów rozwojowych w obszarze elektromobilności w Polsce, Warszawa (in Polish)

2. Benysek G. (2019): Infrastruktura tadowania pojazdów elektrycznych - element sieci Smart Grid, Kraków, październik (in Polish)

3. Bralewski P., Szabłowski Ł., Badyta K, Bujalski W. (2018): Perspektywy rozwoju elektromobilności w Polsce z punktu widzenia Krajowego Systemu Energetycznego. „Nowa Energia” - 4/2018, pp. 6-8 (in Polish)

4. Choudekar P., Asija D. (2013): Overview of smart grid system, International Journal of Electrical and Electronics Engineering Research (IJEEER) ISSN 2250155X, Vol. 3, Issue 1, Mar 2013, pp.259-264.

5. Europejski Instytut Miedzi Cooper Alliance (2018) : Elektromobilność - Pojazdy elektryczne w sieci inteligentnej Smart Grid. (in Polish)

6. Fasiecka O., Marek M. (2018): Odnawialne źródła energii a rozwój elektromobilności. PTiL 4/2018 (44), pp 7-14.

7. Flasza J. (2017): Elektromobilność w Polsce Wyzwania i możliwości z uwzględnieniem inteligentnych instalacji OZE. Autobusy 6/2017, pp. 1196-1198 (in Polish)

8. https://alebank.pl/polski-sposob-na-powszechnainfrastrukture-ladowarek-dla-samochodowelektrycznych-czyli-najciemniej-pod-latarnia/ [dostęp: kwiecień 2020]

9. https://biznesalert.pl/samochody-beda-stabilizowac-siecielektroenergetyczne/ [dostęp: kwiecień 2020]

10. https://www.smart-energy.com/features-analysis/gettingready-to-operate-the-smarter-grid/ [dostęp: kwiecień 20120]

11. https://www.wnp.pl/motoryzacja/energetyka-musi-dlaelektromobilnosci-zbudowac-cwierc-miliona-

kilometrow-sieci,348791.html [dostęp: kwiecień 2020]

12. Kelm P. (2017): Interoperacyjność infrastruktury do ładowania pojazdów elektrycznych z sieciami typu smart grid, Biuletyn techniczno - informacyjny Oddziału tódzkiego Stowarzyszenia Elektryków Polskich, czerwiec, pp. 16-20 (in Polish)

13. Kelm P. (2017): Rynek elektromobility. Biuletyn techniczno - informacyjny Oddziału tódzkiego Stowarzyszenia Elektryków Polskich, grudzień 2017, pp. 12-14 (in Polish)

14. Król E. (2017): Porównanie emisji zanieczyszczeń pojazdów $\mathrm{z}$ napędem elektrycznym i spalinowym. Autobusy, nr 7/8, pp 140-143 (in Polish)

15. Krupa K., Kamiński J. (2017): - Analiza wpływu rozwoju elektromobilności na zużycie energii zlektrycznej w Polsce. Rynek Energii 12/2017, pp. 8-13.

16. Marchel P., Paska J., Michalski Ł. (2018): Analiza wpływu rozwoju elektromobilności na zapotrzebowanie na moc i energię w krajowym systemie elektromobilności, Rynek energii elektrycznej, Aktualne problemy energetyki. pp. 67-76 (in Polish)

17. Ministerstwo Energii - Plan Rozwoju Elektromobilności w Polsce „Energia do przyszłości”, 2018 (in Polish)

18. PSPA: Barometr Nowej elektromobilności 2019/2020, Warszawa 2019 (in Polish)

19. PSPA: Raport, Pojazdy elektryczne jako element sieci elektroenergetycznych, Warszawa 2018

20. PTPiREE: Energetyka dystrybucja $i$ przesyl, Raport, Poznań, maj 2019 (in Polish)

21. Raporty prasowe PZPM (in Polish)
22. Sipiński D., Bolesta K. (2016): Polityka Insight, Cicha rewolucja $w$ energetyce, Elektromobilność $w$ Polsce. Kluczowe wnioski i rekomendacje, (in Polish)

23. Zieliński S.J. (2017): Smart Grid i nowe narzędzia informatyczne, Biuletyn techniczno - informacyjny Oddziału łódzkiego Stowarzyszenia Elektryków Polskich, grudzień 2017, pp 2-4 (in Polish)

\section{Biographical notes}

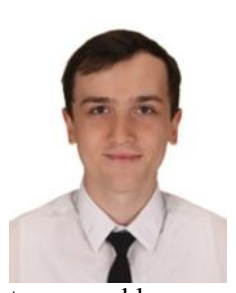

Mikołaj Koltonowski 4th year student of Power Engineering at the Faculty of Mechanical Engineering of the Koszalin University of Technology. The theme of engineering work is "a project of $10 \mathrm{~kW} 75{ }^{\circ} \mathrm{C}$ heat pump based on the compressor Emmerson." The author's area of interest is related to renewable energy sources as well as heating and cooling technology.

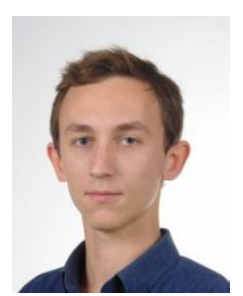

Remigiusz Koltonowski is a final year student of Mechanical Engieneering at the Koszalin University of Technology and works as a CAD constructor. He is interested in the development of renewable energy sources and modern technology.

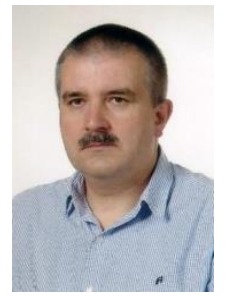

Stanisław Palubicki received his M.Sc. degree in Mechanics and Machine Design from Koszalin University of Technology in 2014.. Currently a PhD student at the Department of Production Engineering at the Koszalin University of Technology. The research undertaken as part of the doctoral dissertation is aimed at developing a method of predicting the effects of heat (linear welding energy) on changes in the structure of the joint, determining its quality, using actual input parameters of the welding process, such as current, arc voltage and welding speed. He is the author and co-author of several scientific articles and oral presentations at international and national conferences in the above field is interested in the development of renewable energy sources. 
